Web Jurnal:

http://ejournal.kemenperin.go.id/jli

\title{
Pengaruh penyalut maltodekstrin terhadap produk mikrokapsul minyak jahe dengan teknik spray drying
}

\section{Effect of maltodextrin coating on ginger oil microcapsule products using spray drying technique}

\author{
Fitriana Djafar ${ }^{1}$, Muhammad Dani Supardan*2,3 \\ 1 Balai Riset dan Standardisasi Industri Banda Aceh \\ Jl. Cut Nyak Dhien No. 377, Lamteumen Timur, Banda Aceh, Indonesia 23236 \\ 2 Jurusan Teknik Kimia Universitas Syiah Kuala, \\ Kopelma Darussalam, Banda Aceh, Indonesia 23111 \\ 3 Atsiri Research Center Universitas Syiah Kuala \\ Kopelma Darussalam, Banda Aceh, Indonesia 23111 \\ * e-mail: m.dani.supardan@unsyiah.ac.id
}

\begin{tabular}{l}
\hline INFO ARTIKEL \\
\hline Sejarah artikel: \\
Diterima: \\
1 Februari 2019 \\
Direvisi: \\
30 Mei 2019 \\
Diterbitkan: \\
28 Juni 2019
\end{tabular}

Kata kunci:

maltodekstrin; mikroenkapsulasi; minyak jahe; spray drying

\begin{abstract}
ABSTRAK
Penelitian ini bertujuan untuk membuat mikrokapsul minyak jahe dengan menggunakan teknik spray drying. Bahan penyalut yang digunakan adalah maltodekstrin. Variabel penelitian yang dipelajari adalah konsentrasi maltodekstrin yaitu 10, 20 dan $30(\%-b / v)$ dan rasio minyak jahe terhadap maltodekstrin yaitu 1:8, 1:10, 1:12 dan 1:14 (b/v). Variabel penelitian dengan rendemen tertinggi akan digunakan untuk mempelajari pengaruh variasi suhu inlet proses spray drying (160, 170, 180 dan $190{ }^{\circ} \mathrm{C}$ ). Hasil analisis gas kromatografi-spektrofotometri massa menunjukkan bahwa ada lima komponen terbesar yang terdapat dalam minyak jahe yaitu benzene $(28,62 \%)$, zingiberene $(19,46 \%)$, $\beta$-bisabolene $(13,48 \%)$, cyclohexane $(12,59 \%)$ dan farnesene $(5,83 \%)$. Rendemen produk mikrokapsul minyak jahe tertinggi diperoleh pada perlakuan konsentrasi maltodekstrin 30\% dan rasio minyak jahe terhadap maltodekstrin 1:14 yaitu sebesar 37 gram. Hasil penelitian juga menunjukkan bahwa peningkatan suhu inlet spray drying memberikan pengaruh terhadap kadar air, kadar minyak total, kadar minyak di permukaan dan kadar minyak terperangkap mikrokapsul minyak jahe. Hasil analisis Scanning Electron Microscopy menunjukkan mikrostruktur produk mikrokapsul minyak atsiri jahe yang dihasilkan memiliki bentuk yang bervariasi.
\end{abstract}

Keywords:

maltodexstrin; microencapsulation; ginger essential oil; spray drying

\section{ABSTRACT}

This study aims to make ginger oil microcapsules using spray drying technique. Maltodextrine was used as a coating material. The process variables studied were maltodextrin concentration 10, 20 and $30(\%-w / v)$ and ratio of ginger oil to maltodextrin 1:8, 1:10, 1:12 and 1:14 (w/v). The best process variable with the highest product yield will be used to investigate the effect of inlet temperature variations of spray drying process (160, 170, 180 and $190{ }^{\circ} \mathrm{C}$ ). The results of gas chromatography-mass spectroscopy analysis showed that the five largest components contained in ginger oil were benzene $(28.62 \%)$, zingiberene $(19.46 \%)$, $\beta$-bisabolene $(13.48 \%)$, cyclohexane $(12.59 \%)$ and farnesene (5.83\%). The highest yield of ginger essential oil microcapsule products was obtained 37 grams at maltodextrin concentration $30 \%$ and ratio of ginger oil to maltodextrin 1:14. The experimental results showed that the inlet temperature of spray drying affected the moisture content, total oil content, surface oil content, and trapped oil content of the ginger oil microcapsules products. Meanwhile, Scanning Electron Microscopy analysis results showed that the microstructure of ginger essential oil products from several research treatments generally have various shape. 


\section{Pendahuluan}

Jahe (Zingiber officinale Rosc.) merupakan hasil rempah yang cukup potensial di Indonesia. Beberapa hasil penelitian telah melaporkan berbagai khasiat dari rimpang jahe, di antaranya memiliki aktivitas antimikroba, antioksidan, dan anti-imflamasi (Fernandes et al., 2016). Kebutuhan komoditas jahe untuk berbagai keperluan terus meningkat dari waktu ke waktu. Rimpang jahe segar mengandung minyak atsiri sekitar $0,4 \%$. Sementara itu, kandungan minyak atsiri dalam rimpang jahe kering sekitar 1-3\% (Supardan et al., 2009; Salea et al., 2017). Minyak atsiri jahe merupakan salah satu produk olahan jahe yang mempunyai banyak manfaat. Minyak atsiri jahe diketahui memiliki berbagai fungsi, diantaranya digunakan dalam industri kosmetik, makanan, aromaterapi dan farmasi. Namun minyak atsiri merupakan bahan yang rentan terhadap suhu tinggi, sinar UV, oksidasi, dan kelembaban sehingga diperlukan solusi yang tepat untuk mengatasi permasalahan tersebut (Petrović et al., 2010). Kerusakan oksidatif antara lain akan berdampak terbentuknya flavor yang tidak enak, stabilitas umur simpan turun dan penurunan sifat sensoris (Velasco et al., 2003). Selain itu, penanganan, pengemasan dan penyimpanan bahan yang berbentuk cair relatif lebih sulit daripada bahan yang berbentuk padat (Yuliani et al., 2007). Teknik mikroenkapsulasi merupakan salah satu cara yang tepat sebagai solusi untuk mengatasi permasalahan tersebut.

Mikroenkapsulasi merupakan suatu teknik untuk mengkonversi bentuk cairan menjadi padat atau bubuk dengan cara membungkus cairan tersebut menggunakan suatu bahan penyalut/pengkapsul dalam ukuran yang

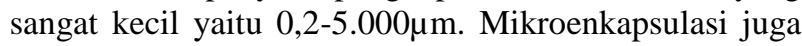
merupakan teknik yang digunakan untuk melindungi bahan inti (core) yang berbentuk cair menjadi padatan sehingga penanganannya lebih mudah dan dapat melindungi bahan inti dari kehilangan flavor (Gharsallaoui et al., 2007; Nedovic et al., 2011). Kegunaan dari teknik mikroenkapsulasi ini antara lain adalah: (i) melindungi dari efek buruk yang disebabkan oleh pengaruh cahaya, kelembaban dan oksigen; (ii) mengendalikan pelepasan senyawa aktif dari bahan; dan (iii) melindungi senyawa aktif dalam bahan yang peka terhadap lingkungannya. Selain itu, teknik ini dapat digunakan untuk meningkatkan nutrisi suatu bahan serta memperpanjang umur simpan tanpa mengurangi sifat fisik, kimia, atau fungsionalnya (Ye et al., 2018). Keunikan dari produk mikrokapsul ini adalah kecilnya partikel yang tersalut dan dapat digunakan lebih lanjut untuk berbagai keperluan (Nugraheni et al., 2015).

Spray drying adalah metode tertua dan merupakan teknik enkapsulasi yang paling banyak digunakan (Khasanah et al., 2015). Metode spray drying mempunyai beberapa keunggulan diantaranya yaitu ketersediaan peralatan, biaya prosesnya rendah, jenis bahan penyalut yang digunakan lebih beragam, retensi bahan mudah menguap dengan baik, dapat diproduksi secara kontinyu dalam skala besar dan dapat digunakan untuk bahan yang tidak tahan panas (titk lebur rendah). Hal ini disebabkan dalam proses spray drying akan terbentuk lapisan film yang mengelilingi droplet sehingga suhu pemanasan di luar droplet tidak akan merusak material intinya. Penelitian tentang enkapsulasi minyak jahe dengan teknik spray drying sebelumnya pernah dilakukan oleh beberapa peneliti. Simon-Brown et al. (2016) menggunakan bahan penyalut maltodekstrin dan gum arab. Fernandes et al. (2016) menggunakan campuran gum arab, maltodextrin dan inulin sebagai bahan penyalut.

Pemilihan jenis penyalut atau bahan pengkapsul (encapsulating material/wall) merupakan salah satu faktor penting dalam teknik mikroenkapsulasi. Kapsul yang dihasilkan dapat berfungsi baik jika menggunakan bahan penyalut yang sesuai. (Botrel et al., 2014). Maltodekstrin merupakan salah satu penyalut yang baik dan sering digunakan karena kemampuannya dalam membentuk emulsi, memiliki viskositas yang rendah, mudah ditemukan, mudah penanganan prosesnya, cepat terdispersi, memiliki kelarutan yang tinggi, mampu membentuk matrik sehingga mengurangi terjadinya pencoklatan, mampu menghambat kristalisasi, memiliki daya ikat yang kuat dan bersifat stabil pada emulsi minyak dalam air (Laohasongkram et al., 2011). Selain itu, maltodekstrin juga memiliki kemampuan yang sangat baik dalam menghadapi oksidasi sehingga mikrokapsul yang dihasilkan dapat mempunyai umur simpan yang lebih baik (Gharsallaoui et al., 2007).

Penelitian ini bertujuan untuk mempelajari pengaruh variabel proses yaitu variasi konsentrasi maltodekstrin, rasio minyak jahe terhadap bahan penyalut maltodekstrin (SF rasio) dan suhu inlet proses pada proses pembuatan mikrokapsul minyak jahe menggunakan teknik spray drying. Hasil penelitian ini diharapkan dapat dikembangkan untuk penggunaan minyak jahe dalam berbagai keperluan industri makanan, minuman dan farmasi.

\section{Metode}

Bahan utama yang digunakan adalah minyak jahe emprit yang diperoleh dari Semarang, Jawa Tengah. Bahan pengkapsul maltodekstrin DE-10 diperoleh dari Indo Food Chem Jakarta. Alat yang digunakan adalah Spray Dryer (LabPlant Spray Dryer SD-05, West Yorkshire, UK), Homogenizer (IKA T25 Digital Ultra Turrax, Artisan Tech Group, Champaign, USA), neraca analitik (Kern, Germany), dan beberapa peralatan gelas.

\subsection{Mikroenkapsulasi minyak jahe}

Mikroenkapsulasi minyak jahe dilakukan dengan menggunakan metode spray drying. Kegiatan ini terdiri dari dua tahap, yaitu:

\section{1) Pembuatan emulsi}

Pembuatan emulsi dilakukan dengan menggunakan 3 (tiga) variasi konsentrasi bahan penyalut yaitu $10 \%$, $20 \%$ dan $30 \%(\mathrm{~b} / \mathrm{v})$. Bahan penyalut yang digunakan adalah maltodekstrin. Sejumlah tertentu maltodekstrin ditambahkan ke dalam aquadest hingga didapatkan suspensi dengan konsentrasi yang diinginkan. Campuran bahan dihomogenkan menggunakan homogenizer secara perlahan-lahan dengan kecepatan 16.000 rpm selama 30 menit dimana maltodekstrin ditambahkan sedikit demi sedikit ke dalam aquadest untuk mempermudah proses 
pencampuran. Selanjutnya dilakukan homogenisasi antara minyak jahe dan maltodekstrin untuk mendapatkan campuran bahan dengan rasio minyak jahe terhadap maltodekstrin 1:8, 1:10, 1:12 dan 1:14 (b/v).

\section{2) Pembuatan mikrokapsul minyak jahe}

Campuran selanjutnya dikeringkan dengan spray dryer pada laju umpan $15 \mathrm{~mL} /$ menit dengan suhu inlet $170{ }^{\circ} \mathrm{C}$ dan suhu outlet $160-170{ }^{\circ} \mathrm{C}$. Produk yang dihasilkan merupakan mikrokapsul minyak jahe selanjutnya disimpan untuk dianalisis. Variabel proses terbaik dengan hasil produk tertinggi akan digunakan untuk mempelajari pengaruh variasi suhu proses menggunakan 4 taraf perlakuan (160, 170, 180 dan 190 $\left.{ }^{\circ} \mathrm{C}\right)$. Diagram alir mikroenkapsulasi minyak atsiri jahe disajikan pada Gambar 1 .

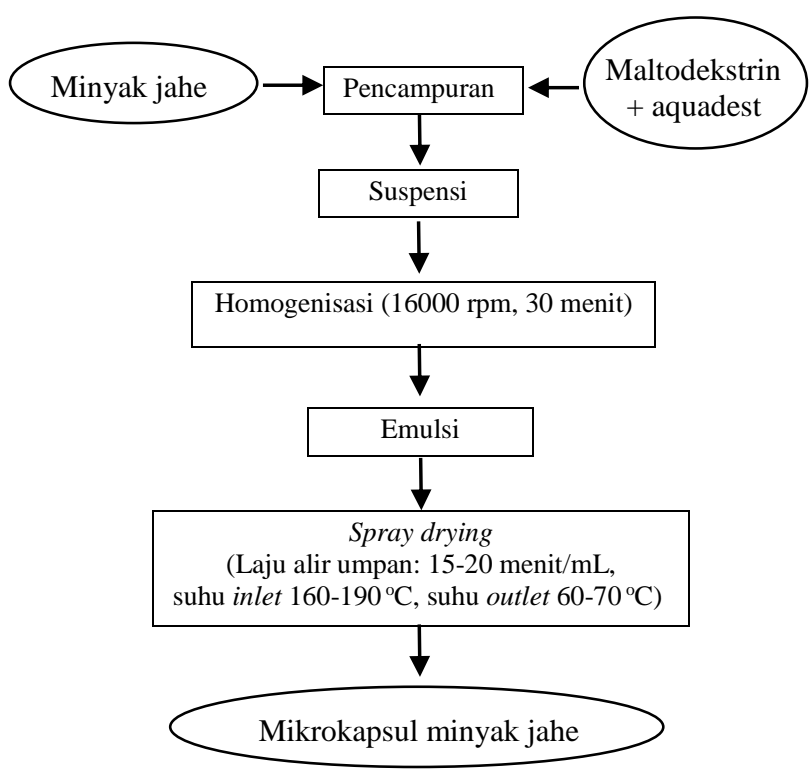

Gambar 1. Diagram alir pembuatan mikrokapsul minyak jahe

\subsection{Analisis bahan baku dan produk}

Analisis awal dilakukan terhadap bahan baku minyak jahe untuk mengidentifikasi komponen-komponen yang ada dalam minyak jahe menggunakan gas kromatografi spektrofotometri massa, GC-MS (QP 2010 Shimadzu, Japan). Beberapa analisis terhadap produk mikrokapsul minyak jahe yang dilakukan adalah kadar air serta minyak total, minyak di permukaan dan minyak terperangkap (Yuliani et al., 2007), Analisis morfologis mikrokapsul minyak jahe menggunakan Scanning Electron Microscopy, SEM (JEOL JSM-5310 LV, Japan).

\section{Hasil dan pembahasan}

\subsection{Profil minyak jahe}

Minyak jahe secara visual berwarna kuning terang dan berbau khas. Kromatogram hasil analisis GC-MS minyak jahe menunjukkan adanya beberapa senyawa terpene yang merupakan fraksi ringan dalam minyak jahe yaitu $\alpha$-pinene, camphene, myrcene dan cineole. Fraksi-fraksi ringan dalam minyak jahe umumnya memiliki angka putaran optik yang bernilai positif. Mutu minyak jahe akan menjadi rendah bila memiliki banyak kandungan fraksi ringan karena minyak jahe yang bermutu baik memiliki angka putaran optik yang bernilai negatif. Komponen-komponen yang terkandung dalam minyak jahe disajikan pada Tabel 1.

Tabel 1.

Komponen kimia dalam minyak jahe

\begin{tabular}{llll}
\hline No & $\begin{array}{l}\text { Waktu Retensi } \\
\text { (menit) }\end{array}$ & $\begin{array}{l}\% \\
\text { Area }\end{array}$ & Nama Komponen \\
\hline 1 & 3,023 & 0,69 & $\alpha$-pinene \\
2 & 3,664 & 2,96 & Champene \\
3 & 18,775 & 1,04 & $\beta$-himachalene \\
4 & 19,104 & 1,12 & Borneol \\
5 & 19,408 & 1,81 & Germacrene-D \\
6 & 19,665 & 19,46 & Zingiberene \\
7 & 19,823 & 13,48 & $\beta$-bisabolene \\
8 & 20,110 & 1,85 & E-citral \\
9 & 20,218 & 1,99 & Zingiberene \\
10 & 20,611 & 5,83 & Farnesene \\
11 & 20,912 & 1,03 & Neryl Acetat \\
12 & 21,199 & 12,59 & Cyclohexane \\
13 & 21,398 & 28,62 & Benzene \\
14 & 23,794 & 0,76 & Geraniol \\
15 & 24,812 & 1,79 & 2 -Naphtalene \\
16 & 29,493 & 1,09 & $\alpha$-cedrol \\
17 & 31,446 & 1,42 & trans-Caryophyllene \\
18 & 32,008 & 1,09 & Cubenol \\
19 & 34,330 & 1,41 & $\alpha$-cedrol \\
\hline
\end{tabular}

Data hasil identifikasi komponen menggunakan GCMS pada Tabel 1 dapat diketahui bahwa minyak jahe mengandung lima komponen terbesar yaitu: benzene, zingiberene, $\beta$-bisabolene, cyclohexane dan farnesene. Minyak mengandung beberapa komponen pemberi aroma khas pada jahe yaitu zingiberene, $\beta$-bisabolene dan geraniol (Hartuti dan Supardan, 2013). Komponenkomponen fraksi ringan diperoleh pada awal proses penyulingan mempunyai angka putaran optik yang positif. Komponen-komponen yang sebaiknya terkandung dalam minyak jahe adalah senyawa-senyawa fraksi berat yaitu senyawa sesquiterpene (zingeberen, zingeron, damar dan pati), senyawa phenol (gingerol dan shogaol), dan senyawa monoterpene (citral dan borneol). Hasmita et al. (2015) melaporkan bahwa perbedaan komposisi dalam minyak jahe dapat disebabkan oleh spesies tanaman, kondisi produksi, waktu panen dan iklim.

\subsection{Pengaruh konsentrasi maltodekstrin dan rasio minyak jahe terhadap maltodekstrin}

Pengaruh konsentrasi maltodekstrin dan rasio minyak jahe terhadap maltodekstrin terhadap rendemen produk mikrokapsul minyak jahe disajikan pada Gambar 2. Secara umum terlihat bahwa semakin besar konsentrasi maltodekstrin dan rasio minyak jahe terhadap maltodekstrin yang digunakan maka semakin besar jumlah rendemen produk mikrokapsul minyak atsiri jahe yang diperoleh. Dapat disimpulkan bahwa konsentrasi maltodekstrin dan rasio minyak jahe terhadap maltodekstrin memberikan pengaruh terhadap peningkatan rendemen produk mikrokapsul minyak jahe 
pada proses spray drying. Kecenderungan hasil yang sama juga telah dilaporkan oleh Hermanto et al. (2016) pada proses pembuatan mikrokapsul cinnamon oil.

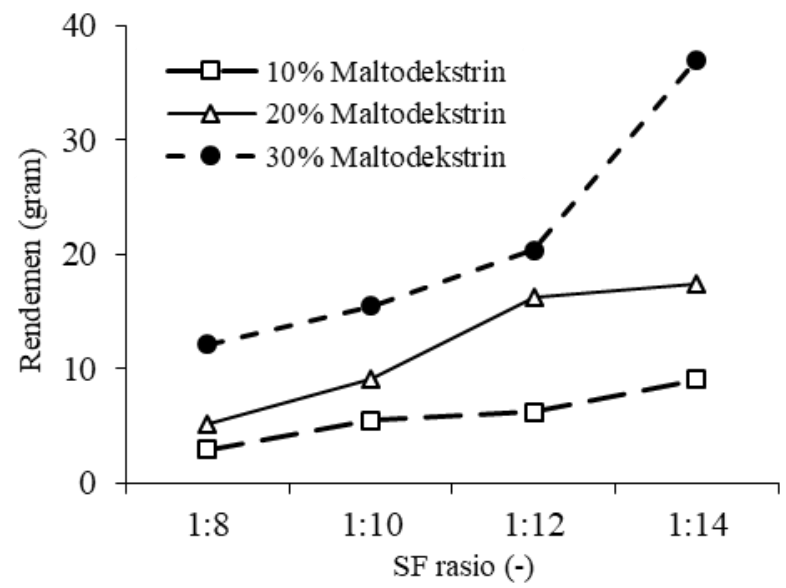

Gambar 2. Pengaruh konsentrasi maltodekstrin dan SF rasio terhadap rendemen mikrokapsul minyak jahe

\subsection{Pengaruh suhu inlet spray drying}

Pada variabel proses dengan rendemen perolehan hasil produk mikrokapsul tertinggi (konsentrasi maltodekstrin $30 \%$ dan SF rasio 1:14) dilakukan variasi suhu inlet proses menggunakan 4 taraf perlakuan (160, 170, 180 dan $190{ }^{\circ} \mathrm{C}$ ). Variasi suhu inlet tersebut dilakukan untuk melihat pengaruhnya terhadap rendemen produk mikrokapsul minyak atsiri jahe. Adapun pengaruh variasi suhu inlet terhadap rendemen mikrokapsul minyak jahe disajikan pada Gambar 3.

Sebagaimana terlihat pada Gambar 3, semakin besar suhu inlet yang digunakan maka semakin besar jumlah rendemen produk mikrokapsul minyak atsiri jahe yang diperoleh dimana rendemen tertinggi diperoleh pada suhu inlet $190^{\circ} \mathrm{C}$ yaitu 50,77\%. Dapat disimpulkan bahwa suhu inlet mempunyai pengaruh yang cukup penting terhadap rendemen produk mikrokapsul minyak jahe pada proses spray drying.

Kadar air merupakan salah satu parameter penting yang terkait dengan stabilitas produk selama proses penyimpanan dan kemudahan mengalir produk mikrokapsul (Premi dan Sharma, 2017). Kadar air produk mikrokapsul minyak atsiri jahe berkisar antara $0,86-2,07 \%$ dengan rata-rata $1,58 \%$. Kadar air yang terkandung dalam produk spray drying umumnya berkisar 2-6\% (Yuliani et al., 2007). Suhu inlet spray drying mempengaruhi kadar air produk mikrokapsul yang dihasilkan (Botrel et al., 2014). Pengaruh suhu inlet spray drying terhadap kadar air produk mikrokapsul minyak jahe disajikan pada Gambar 4.

Gambar 4 menunjukkan bahwa peningkatan suhu inlet spray drying menyebabkan terjadinya penurunan kadar air mikrokapsul minyak atsiri jahe. Hal ini sesuai dengan penelitian Yuliani et al. (2007) terhadap oleoresin minyak jahe dimana peningkatan suhu inlet spray drying akan menyebabkan penurunan kadar air mikrokapsul.

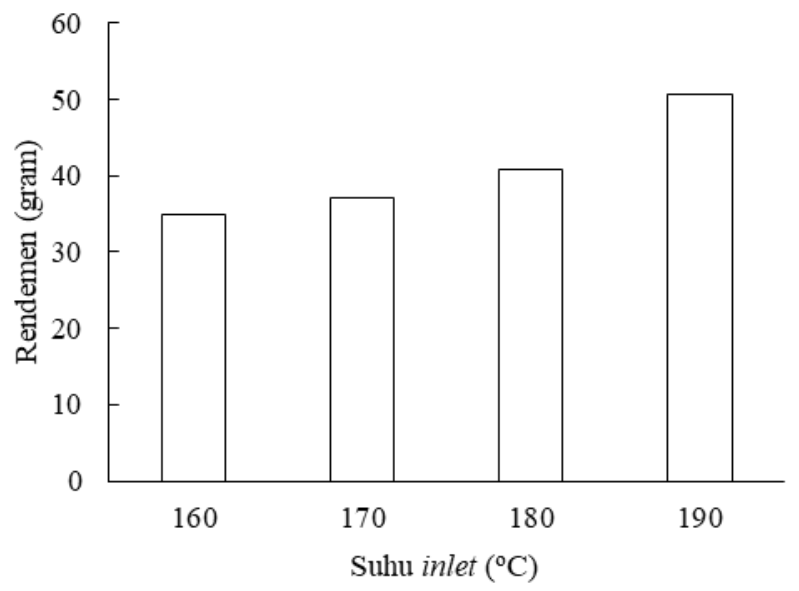

Gambar 3. Pengaruh suhu inlet terhadap rendemen produk mikrokapsul minyak jahe

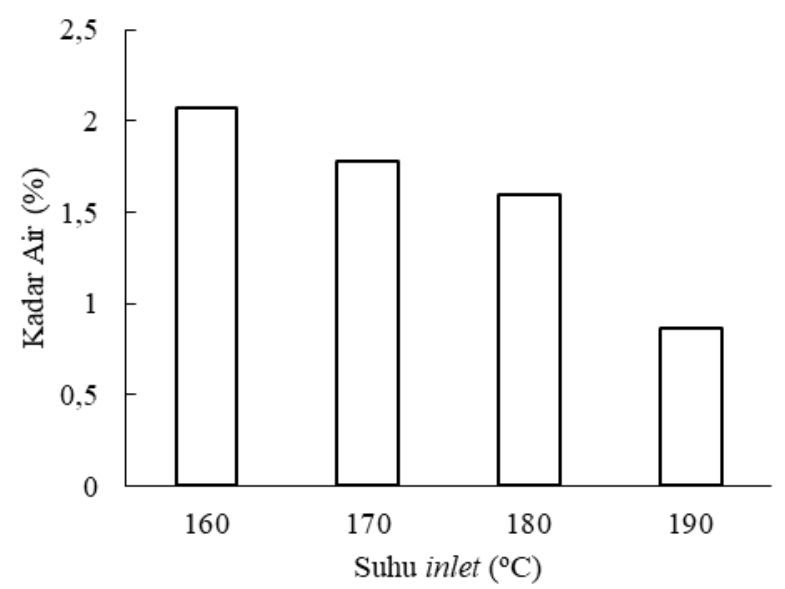

Gambar 4. Pengaruh suhu inlet terhadap kadar air produk mikrokapsul minyak jahe

Sementara itu, kadar minyak total merupakan jumlah minyak yang ada pada mikrokapsul, baik yang terdapat di dalam maupun di luar yaitu yang menempel pada permukaan mikrokapsul (Yuliani et al., 2007). Kadar minyak total produk mikrokapsul minyak atsiri jahe disajikan pada Gambar 5. Sebagaimana ditunjukkan pada Gambar 5, suhu inlet berpengaruh terhadap minyak total produk mikrokapsul minyak atsiri jahe yang diperoleh. Semakin besar suhu inlet yang digunakan maka jumlah minyak total yang terdapat pada produk mikrokapsul minyak atsiri jahe yang diperoleh juga semakin meningkat.

Minyak di permukaan mikrokapsul menunjukkan banyaknya minyak yang terdapat pada permukaan luar dinding mikrokapsul (Supriyadi dan Rujita, 2013). Stabilitas bahan aktif selama proses penyimpanan sangat terkait dengan jumlah minyak di permukaan mikrokapsul. Minyak yang terdapat pada permukaan dinding mikrokapsul tidak dikehendaki keberadaannya. Hal ini disebabkan minyak tidak terkapsulkan yaitu minyak yang terdapat pada permukaan, akan terekspos ke lingkungan sekitarnya dan dapat mengalami kerusakan (Yuliani et al., 2007). Persentase minyak di permukaan mikrokapsul minyak jahe disajikan pada Gambar 6. 


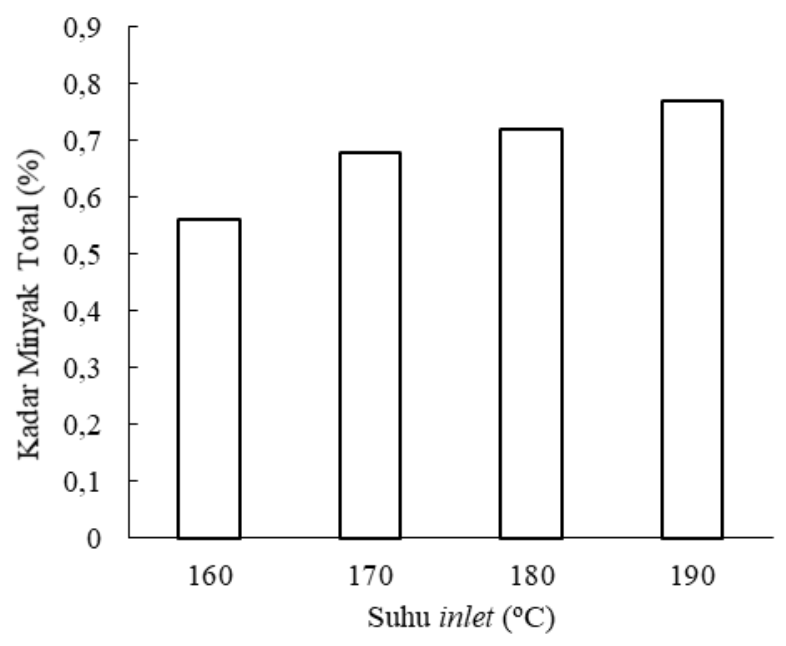

Gambar 5. Pengaruh suhu inlet terhadap kadar minyak total produk mikrokapsul minyak jahe

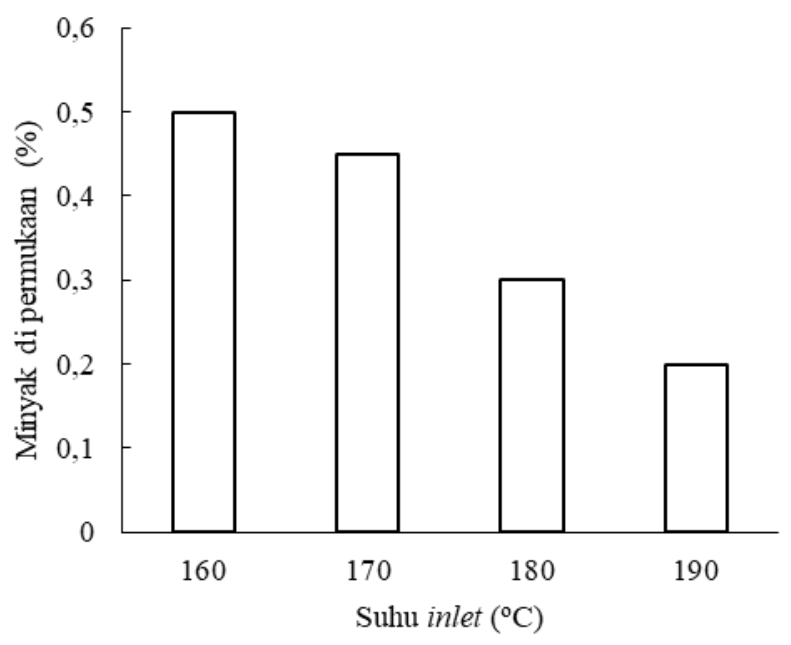

Gambar 6. Pengaruh suhu inlet terhadap minyak di permukaan produk mikrokapsul minyak jahe

Gambar 6 menunjukkan bahwa suhu inlet berpengaruh terhadap minyak di permukaan produk mikrokapsul minyak atsiri jahe. Semakin besar suhu inlet yang digunakan maka jumlah minyak di permukaan produk mikrokapsul minyak jahe yang diperoleh semakin rendah. Botrel et al. (2014) telah melaporkan penurunan kadar minyak di permukaan pada proses mikroenkapsulasi dengan menggunakan maltodekstrin dan inulin sebagai bahan penyalut. Nilai minyak dipermukaan yang semakin rendah menunjukkan bahwa banyak bahan inti yang terperangkap. Semakin kecil jumlah minyak di permukaan mikrokapsul maka produk mikrokapsul yang diperoleh semakin baik dan semakin stabil bahan aktifnya.

Minyak terperangkap merupakan banyaknya minyak atsiri yang terperangkap di dalam mikrokapsul. Produk mikrokapsul dengan persentase minyak terperangkap tinggi menunjukkan bahwa jumlah minyak yang dapat terlindungi oleh bahan penyalut juga banyak. Persentase minyak terperangkap pada mikrokapsul minyak jahe disajikan pada Gambar 7.

Pada Gambar 7 terlihat bahwa semakin besar suhu inlet yang digunakan maka jumlah minyak terperangkap mikrokapsul minyak jahe yang diperoleh semakin tinggi. Semakin banyak jumlah minyak terperangkap menunjukkan jumlah minyak yang terdapat pada permukaan menjadi semakin berkurang.

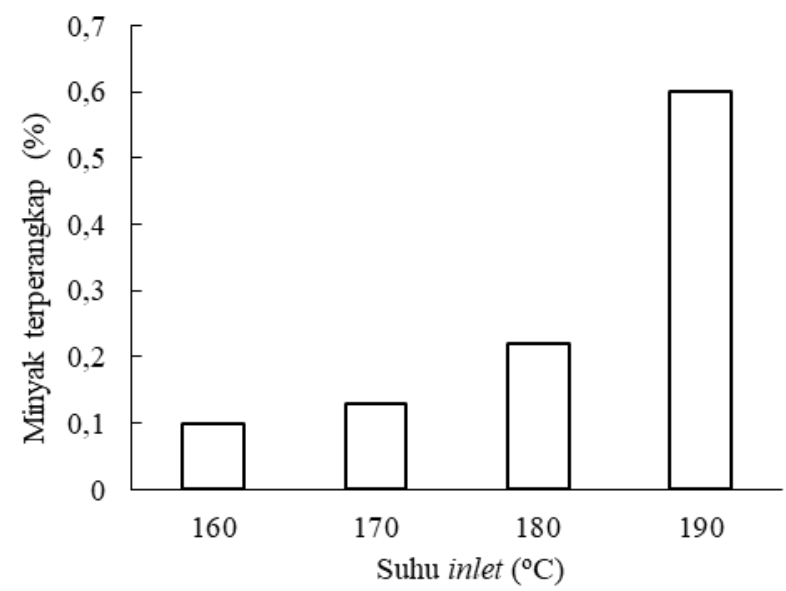

Gambar 7. Pengaruh suhu inlet terhadap minyak terperangkap produk mikrokapsul minyak jahe

\subsection{Mikrostruktur mikrokapsul minyak jahe}

Morfologi mikrokapsul akan berpengaruh terhadap karakteristik produk mikrokapsul yang dihasilkan seperti minyak di permukaan, pelepasan bahan aktif, retensi dan lain-lain (Yuliani et al., 2007). Struktur morfologi dari produk mikrokapsul minyak atsiri jahe diamati dengan menggunakan SEM. Hasil mikrokapsul yang baik adalah berbentuk bulat tanpa kerutan yang berarti bahan aktif terkapsul dengan baik (Khasanah et al., 2015). Mikrostruktur produk mikrokapsul minyak jahe dengan perbesaran 5000x yang dihasilkan pada konsentrasi maltodekstrin $30 \%$, SF rasio 1:14 dengan suhu inlet $160^{\circ} \mathrm{C}-190^{\circ} \mathrm{C}$ disajikan pada Gambar 8 .

Teknik mikroenkapsulasi menggunakan spray drying umumnya menghasilkan produk berbentuk bola (Botrel et al., 2014). Gambar 8(a) menunjukkan bahwa mikrostruktur produk mikrokapsul minyak jahe yang dihasilkan dengan suhu inlet $160^{\circ} \mathrm{C}$ memiliki bentuk keriput lebih banyak. Hal ini disebabkan maltodekstrin sebagai bahan penyalut tidak menyalut bahan inti dengan baik. Pada suhu inlet $170^{\circ} \mathrm{C}$, mikrostruktur produk mikrokapsul minyak jahe yang dihasilkan sebagian memiliki bentuk bulat dan sebagian berbentuk keriput (Gambar 8(b)). Hal ini diduga karena sebagian maltodekstrin sebagai bahan penyalut telah menyalut dengan baik. Gambar 8(c) menunjukkan bahwa mikrostruktur produk mikrokapsul minyak atsiri jahe yang dihasilkan dengan suhu inlet $180^{\circ} \mathrm{C}$ hampir semua memiliki bentuk yang mengempis. Mikrokapsul yang mempunyai bentuk mengempis, diduga akibat adanya peristiwa ballooning selama proses spray drying. Hermanto et al. (2016) juga mengamati fenomena yang sama pada proses pembuatan mikrokapsul cinnamon oil.

Ballooning merupakan suatu peristiwa penggelembungan partikel mikrokapsul selama proses spray drying. Ballooning dapat disebabkan oleh beberapa factor diantaranya suhu spray drying yang tinggi dan adanya ketidaksesuaian antara kondisi spray 
drying dengan bahan penyalut (Khasanah et al., 2015). Namun, dinding kapsul akan pecah dan partikel akan mengempis jika dinding kapsul tidak cukup kuat untuk menahan tekanan yang ada di dalam partikel mikrokapsul. Komponen-komponen volatil dapat hilang dari dalam kapsul karena peristiwa ballooning tersebut. Sementara itu, Gambar 8(d) menunjukkan bahwa mikrostruktur produk mikrokapsul minyak atsiri jahe yang dihasilkan sebagian besar berbentuk bola. Hal ini menunjukkan bahwa maltodekstrin sebagai bahan penyalut telah menyalut bahan aktif dengan sempurna.

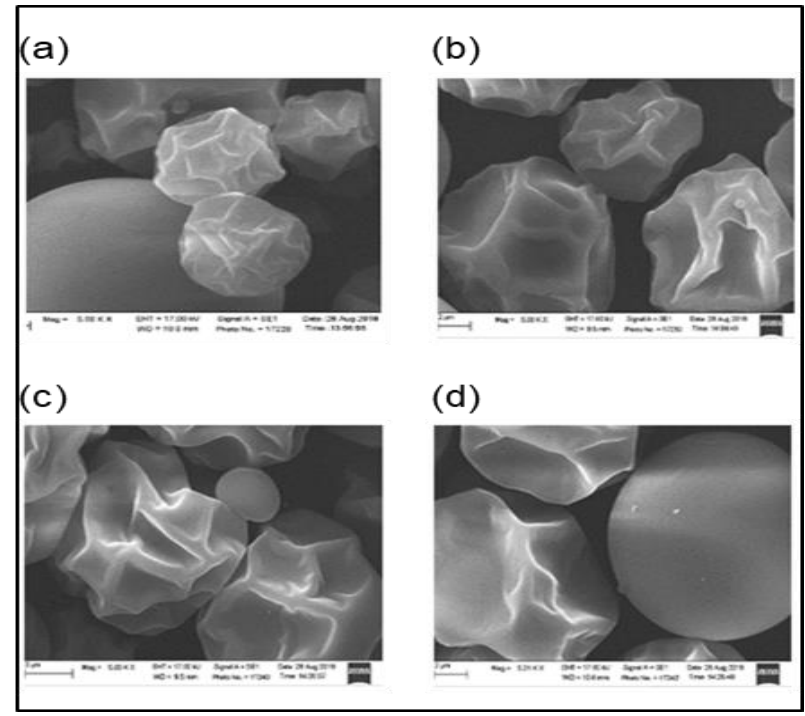

Gambar 8. Mikrostruktur produk mikrokapsul minyak jahe dengan suhu inlet: (a) $160^{\circ} \mathrm{C}$; (b) $170^{\circ} \mathrm{C}$; (c) $180^{\circ} \mathrm{C}$; dan (d) $190^{\circ} \mathrm{C}$.

\section{Kesimpulan}

Hasil penelitian menunjukkan konsentrasi maltodekstrin dan rasio minyak jahe terhadap maltodekstrin yang digunakan memberikan pengaruh terhadap produk mikroenkapsulasi minyak jahe dengan teknik spray drying. Hasil GC-MS menunjukkan bahwa ada lima komponen terbesar yang terkandung dalam minyak jahe yaitu benzene, zingiberene, $\beta$-bisabolene, cyclohexane, dan farnesene. Produk mikrokapsul minyak atsiri jahe dengan rendemen tertinggi diperoleh pada perlakuan konsentrasi bahan penyalut maltodekstrin 30\% dengan rasio minyak jahe terhadap maltodekstrin 1:14 yaitu sebesar 37 gram. Pada kondisi tersebut, suhu inlet $190^{\circ} \mathrm{C}$ menghasilkan rendemen mikrokapsul tertinggi.

Kadar air produk mikrokapsul minyak atsiri jahe relatif rendah yaitu berkisar antara 0,86-2,07\%. Semakin besar suhu inlet yang digunakan maka jumlah minyak total yang terdapat pada produk mikrokapsul minyak atsiri jahe yang diperoleh juga semakin meningkat. Hasil penelitian menunjukkan bahwa suhu inlet berpengaruh terhadap minyak di permukaan produk mikrokapsul minyak atsiri jahe. Semakin besar suhu inlet yang digunakan maka jumlah minyak di permukaan produk mikrokapsul minyak atsiri jahe yang diperoleh semakin rendah. Sementara itu, semakin besar suhu inlet yang digunakan maka jumlah minyak terperangkap mikrokapsul minyak atsiri jahe yang diperoleh semakin tinggi. Mikrostruktur produk mikrokapsul minyak jahe yang dihasilkan secara umum berbentuk bola. Semakin besar suhu inlet yang digunakan maka produk mikrokapsul minyak jahe yang diperoleh akan semakin baik tersalut oleh bahan penyalutnya.

\section{Ucapan terima kasih}

Ucapan terima kasih kepada Balai Riset dan Standardisasi Industri Banda Aceh dan Jurusan Teknik Kimia Universitas Syiah Kuala yang telah membantu pelaksanaan penelitian.

\section{Daftar pustaka}

Botrel, D.A., de Barros Fernandes, R.V., Borges, S.V., Yoshida, M.I., 2014. Influence of wall matrix systems on the properties of spray-dried microparticles containing fish oil. Food Res. Int. 62, 344-352.

https://doi.org/10.1016/j.foodres.2014.02.003

Fernandes, R.V. de B., Borges, S.V., Silva, E.K., da Silva, Y.F., de Souza, H.J.B., do Carmo, E.L., de Oliveira, C.R., Yoshida, M.I., Botrel, D.A., 2016. Study of ultrasound-assisted emulsions on microencapsulation of ginger essential oil by spray drying. Ind. Crops Prod. 94, 413-423. https://doi.org/10.1016/J.INDCROP.2016.09.010

Gharsallaoui, A., Roudaut, G., Chambin, O., Voilley, A., Saurel, R., 2007. Applications of spray-drying in microencapsulation of food ingredients: An overview. Food Res. Int. 40, 1107-1121. https://doi.org/10.1016/J.FOODRES.2007.07.004

Hartuti, S., Supardan, M.D., 2013. Optimasi ekstraksi gelombang ultrasonik untuk produksi oleoresin jahe (Zingiber officinale Roscoe) menggunakan Response Surface Methodolgy (RSM). Agritech 33, 415-423.

Hasmita, I., Adisalamun, Alam, P.N., Satriana, Mahlinda, Supardan, M.D., 2015. Effect of drying and hydrodistillation time on the amount of ginger essential oil. IJASEIT 5, 300-303.

Hermanto, R.F., Khasanah, L.U., Kawiji, Atmaka, W., Manuhara, G.J., Utami, R., 2016. Physical characteristics of cinnamon oil microcapsule. IOP Conf. Ser. Mater. Sci. Eng. 107. https://doi.org/10.1088/1757-899X/107/1/012064

Khasanah, L.U., Anandhito, B.K., Rachmawaty, T., Utami, R., Manuhara, G.J., 2015. Pengaruh rasio bahan penyalut maltodekstrin, gum arab, dan susu skim terhadap karakteristik fisik dan kimia mikrokapsul oleoresin daun kayu manis (Cinnamomum burmannii). Agritech 35. https://doi.org/10.22146/agritech.9325

Laohasongkram, K., Mahamaktudsanee, T., Chaiwanichsiri, S., 2011. Microencapsulation of Macadamia oil by spray drying. Procedia Food Sci. 1, 1660-1665. https://doi.org/10.1016/j.profoo.2011. 09.245

Nedovic, V., Kalusevic, A., Manojlovic, V., Levic, S., Bugarski, B., 2011. An overview of encapsulation technologies for food applications. Procedia Food Sci. 1, 1806-1815. https://doi.org/10.1016/j.profoo. 2011.09.265 
Nugraheni, A., Yunarto, N., Sulistyaningrum, N., 2015. Optimasi formula mikroenkapsulasi ekstrak rimpang temulawak (Curcuma xanthorrhiza Roxb.) dengan penyalut berbasis air. J. Kefarmasian Indones. 5, 98105.

Petrović, G.M., Stojanović, G.S., Radulović, N.S., 2010. Encapsulation of cinnamon oil in $\beta$-cyclodextrin. J. Med. Plants Res. 4, 1382-1390.

Premi, M., Sharma, H.K., 2017. Effect of different combinations of maltodextrin, gum arabic and whey protein concentrate on the encapsulation behavior and oxidative stability of spray dried drumstick (Moringa oleifera) oil. Int. J. Biol. Macromol. 105, 1232-1240. https://doi.org/10.1016/J.IJBIOMAC. 2017.07.160

Salea, R., Veriansyah, B., Tjandrawinata, R.R., 2017. Optimization and scale-up process for supercritical fluids extraction of ginger oil from Zingiber officinale var. Amarum. J. Supercrit. Fluids 120, 285-294. https://doi.org/10.1016/J.SUPFLU.2016. 05.035

Simon-Brown, K., Solval, K.M., Chotiko, A., Alfaro, L., Reyes, V., Liu, C., Dzandu, B., Kyereh, E., Goldson Barnaby, A., Thompson, I., Xu, Z., Sathivel, S., 2016. Microencapsulation of ginger (Zingiber officinale) extract by spray drying technology. LWT - Food Sci. Technol. 70, 119-125. https://doi.org/10. 1016/j.lwt.2016.02.030

Supardan, M.D., Ruslan, Satriana, Arpi, N., 2009. Hidrodistilasi minyak jahe (Zingiber officinale Rosc.) menggunakan gelombang ultrasonik. Reaktor 12, 239-244.

Supriyadi, Rujita, A.S., 2013. Karakteristik mikrokapsul minyak atsiri lengkuas dengan maltodekstrin sebagai enkapsulan. J. Teknol. dan Ind. Pangan 24, 201-208. https://doi.org/10.6066/jtip.2013.24.2.201

Velasco, P.J., Dobarganes, C., Márquez-ruiz, G., 2003. Variables affecting lipid oxidation in dried microencapsulated oils. Grasas y Aceites 54, 304314.

Ye, Q., Georges, N., Selomulya, C., 2018. Microencapsulation of active ingredients in functional foods: From research stage to commercial food products. Trends Food Sci. Technol. 78, 167179. https://doi.org/10.1016/J.TIFS.2018.05.025

Yuliani, S., Desmawarni, Harimurti, N., 2007. Pengaruh laju alir umpan dan suhu inlet spray drying pada karakteristik mikrokapsul oleoresin jahe. J. Pascapanen 4, 18-26. https://doi.org/10.1080/ 01629778.2011.597132 